\title{
Effect of Different Chemicals on Root Growth Success of Cuttings in Passion Fruit
}

\author{
R.N. Parse ${ }^{1 *}$, S.B. Mane ${ }^{2}$ and U.M. Naglot ${ }^{3}$ \\ ${ }^{1}$ College of Agriculture, Badnapur, ${ }^{3}$ College of Agriculture, Badnapur, Vasantrao Naik \\ Marathwada Krishi Vidyapeeth Parbhani, Maharashtra, India \\ ${ }^{2}$ College of Agriculture Dr. Balasaheb Sawant Konkan Krishi Vidyapeeth, Dapoli, \\ Maharashtra, India \\ *Corresponding author
}

\section{A B S T R A C T}

\section{Key w ords \\ Cutting, Passion fruit, Root growth, IBA, NAA, Salicyclic acid and Ethanol \\ Article Info \\ Accepted: \\ 20 August 2018 \\ Available Online: \\ 10 September 2018}

The study conducted to know the effect of different chemicals on success of cuttings in passion fruit was carried out at Instructional-cum Research Farm, Department of Horticulture, College of Agriculture, Badnapur during the year 2015-2016. The experiment was laid out in Randomized Block Design with thirteen treatments replicated thrice, comprising each three treatments of IBA, NAA, Salicylic acid, Ethanol and control. The results of the investigation revealed that, there were significant variations in differences with shoot and root growth observations viz. dry weight of shoot $(1.27 \mathrm{~g})$, length of root $(12.75 \mathrm{~cm})$, diameter of root $(1.00 \mathrm{~mm})$ superior in treatment $\mathrm{T}_{1}($ IBA $500 \mathrm{ppm})$ and dry weight of root $(0.44 \mathrm{~g})$ in treatment $\mathrm{T}_{2}$ (IBA $750 \mathrm{ppm}$ ). However, in treatment $\mathrm{T}_{3}$ (IBA 1000 $\mathrm{ppm}$ ) fresh weight of shoot $(3.84 \mathrm{~g})$, dry weight of shoot(1.41g), fresh weight of root (0.86 g) was observed significantly better.

\section{Introduction}

Passion fruit is a perennial climber, cultivated in the tropics. Flowers are borne singly in the axils of leaves at the terminal region of new growth. The vine, bears hen's egg-sized fruits in abundance. They are smooth, ovoid and purple-yellow on ripening. The rind afterwards shrinks and becomes wrinkled. The rind is bordered by white pith, and inside small, hard, black seeds are surrounded separately by a soft, slightly acid, fragrant and juicy orange-yellow pulp (Chadha, 2002).
Passion fruits contain numerous small, black, wedge-shaped seeds that are individually surrounded by deep orange-coloured sacs that contain the juice, the edible part of the fruit. Passion fruit is either eaten fresh or used in commercial juice production. Passion fruit is a high acid food ( $\mathrm{pH}$ 3.2) due to the predominance of two acids, citric (93-96\% of total) and malic (3-6\% of total) acids. Passion fruit also contains about $14.45 \mathrm{~g}$ sugar/ $100 \mathrm{~g}$ of edible portion, including fructose, glucose and sucrose, along with seven other in trace amounts. The acids and sugars add to the 
unique taste and serve as a preservative nature for the tropical fruit. Passion fruit is high in potassium, vitamin $\mathrm{A}$, vitamin $\mathrm{C}$, niacin and fiber and it is low in sodium, cholesterol and saturated fats (Joy et al., 2010). The juice of passion fruit has an excellent flavour and is quite delicious, nutritious and liked for its blending quality. Passion fruits serve a good source of pro vitamin-A, ascorbic acid, riboflavin and niacin and also contains fair amount of minerals sodium, magnesium, sulphur and chlorides (Chand, 1980).

Campbell and Knight (1983) stated that vegetative propagation by cutting for passion fruit cultivation is feasible. The stakes for this purpose should have three nodes young, vigorous and free parts of disease which must these be kept in mist atmosphere. Other factors should also be taken into consideration for the success of the rooting, as the time of withdrawal of stakes, temperature, humidity, light and the quality of the substrate (Ruggiero and Martins., 1987).

\section{Materials and Methods}

The experiment entitle, "Effect of different chemicals on success of cuttings in passion fruit." was carried out at Instructional-cum Research Farm, Department of Horticulture, College of Agriculture, Badnapur, Dist Jalna. Vasantarao Naik Marathwada Krishi Vidyapeeth Parbhani, during the year 20152016. Geographically Badnapur is situated at $19^{\circ} 52^{\prime} 00^{\prime \prime}$ 'North latitude and $75^{\circ} 44^{\prime} 00^{\prime}$ ' East longitudes 75.733 and at $498 \mathrm{~m}$ altitude above sea level and has a sub-tropical climate. The average annual precipitation is $722 \mathrm{~mm}$ with 30 rainy days. The mean daily maximum temperature varies from $21.4^{0} \mathrm{C}$ in December to $32.9^{\circ} \mathrm{C}$ in March. The month of July, August and September were humid and moisture index was positive, winter was cool with moisture index oscillating to deficit side and rest of the period was dry Badnapur is grouped under scarcity zone. The experiment was carried out by planting the cuttings of passion fruit in polythene bags of size $\left(5^{\prime \prime} \times\right.$ 7 “). The polythene bags were punctured to improve the drainage and filled with garden mixture which was prepared by well mixing of one part of soil, one part of sand, one part of well-rotted FYM (1:1:1 proportion of soil, sand and FYM). Pre-treated lower portion of passion fruit cuttings $(1-2 \mathrm{~cm})$ was be treated with different concentration of chemicals by quick dip method for 3-5 seconds and al low to dry for 5 minutes were planted in polythene bags which were properly filled, labeled with tags and placed as per layout.

\section{Results and Discussion}

The observations were recorded on various aspects viz., fresh weight of shoot, dry weight of shoot, length of root, diameter of root, fresh weight of root, dry weight of root of cuttings. The all above observations are presented in table 1.

The highest fresh weight of shoot at 90 days data presented in Table 1 revealed that, maximum fresh weight of shoot $(3.84 \mathrm{~g})$ was observed in treatment $\mathrm{T}_{3}$ (IBA $1000 \mathrm{ppm}$ ) and it was at par with $\mathrm{T}_{12}(3.28 \mathrm{~g}), \mathrm{T}_{11}(3.30 \mathrm{~g}), \mathrm{T}_{9}$ (3.42g), $\mathrm{T}_{10}(3.44 \mathrm{~g}), \mathrm{T}_{8}(3.50 \mathrm{~g}), \mathrm{T}_{7}(3.52 \mathrm{~g}), \mathrm{T}_{4}$ (3.53g), $\mathrm{T}_{5}(3.56 \mathrm{~g}), \mathrm{T}_{6}(3.60 \mathrm{~g}), \mathrm{T}_{1}(3.63 \mathrm{~g})$ and $\mathrm{T}_{2}(3.82 \mathrm{~g})$ and significantly treatments. While, minimum fresh weight of shoot $(3.21 \mathrm{~g})$ was observed in the control i.e. $\mathrm{T}_{13}$.

Maximum dry weight of shoot (1.41 g) at 90 days was observed in treatment $\mathrm{T}_{3}$ (IBA 1000 $\mathrm{ppm})$ and it was at par with $\mathrm{T}_{1}(1.27 \mathrm{~g})$ and $\mathrm{T}_{2}$ $(1.35 \mathrm{~g})$.Which were significantly over rest of the treatments. While, minimum dry weight of shoot $(0.48 \mathrm{~g})$ was observed in treatment control i.e. $\mathrm{T}_{13}$.

The data presented in Table 1 revealed that, maximum length of root $(14.00 \mathrm{~cm})$ was 
observed in treatment $\mathrm{T}_{2}$ (IBA $750 \mathrm{ppm}$ ) and it was at par with $\mathrm{T}_{1}(12.75 \mathrm{~cm})$. While, minimum length of root $(13.25 \mathrm{~cm})$ was observed in treatment control i.e. $\mathrm{T}_{13}$.

Maximum diameter of root $(1.75 \mathrm{~mm})$ was observed in treatment $\mathrm{T}_{4}$ (NAA $500 \mathrm{ppm}$ ) and it was at par with the treatment $\mathrm{T}_{7}(0.72 \mathrm{~mm})$, $\mathrm{T}_{8}(0.79 \mathrm{~mm}), \mathrm{T}_{2}(0.80 \mathrm{~mm}), \mathrm{T}_{9}(0.90 \mathrm{~mm}), \mathrm{T}_{1}$ $(1.00 \mathrm{~mm}), \mathrm{T}_{6}(1.10 \mathrm{~mm})$ and $\mathrm{T}_{5}(1.50 \mathrm{~mm})$.

Which were significantly over rest of the treatments. While, minimum diameter of root $(0.22 \mathrm{~mm})$ was observed in treatment control i.e. $\mathrm{T}_{13}$.
Maximum fresh weight of root $(1.00 \mathrm{~g})$ at 90 days was observed in treatment $\mathrm{T}_{2}$ (IBA 750 $\mathrm{ppm})$ and it was at par with $\mathrm{T}_{3}(0.86 \mathrm{~g})$. Which were significantly superior over rest of the treatment. While, minimum fresh weight of root $(0.19 \mathrm{~g})$ was observed in treatment control i.e. $\mathrm{T}_{13}$.

Maximum dry weight of root $(0.44 \mathrm{~g})$ at 90 days was recorded in treatment $\mathrm{T}_{2}$ (IBA 750 $\mathrm{ppm}$ ) which were significantly superior over rest of the treatments. While, minimum dry weight of root $(0.06 \mathrm{~g})$ was recorded in treatment control i.e. $\mathrm{T}_{13}$ and data presented in table 1 .

Table.1 Effect of chemicals on success of cuttings in passion fruit at 90 days

\begin{tabular}{|l|l|l|l|l|l|l|}
\hline Tr. & $\begin{array}{l}\text { Fresh } \\
\text { weight } \\
\text { shoot }(\mathrm{g})\end{array}$ & $\begin{array}{l}\text { Dry } \\
\text { weight of } \\
\text { shoot }(\mathrm{g})\end{array}$ & $\begin{array}{l}\text { Length of } \\
\text { root }(\mathbf{c m})\end{array}$ & $\begin{array}{l}\text { Diameter } \\
\text { of } \\
(\mathbf{m m})\end{array}$ & $\begin{array}{l}\text { Fresh } \\
\text { weight } \\
\text { root }(\mathrm{g})\end{array}$ & $\begin{array}{l}\text { Dry } \\
\text { weight of } \\
\text { root }(\mathbf{g})\end{array}$ \\
\hline T1 & 3.63 & 1.27 & 12.75 & 1.00 & 0.50 & 0.23 \\
\hline T2 & 3.82 & 1.35 & 14.00 & 0.80 & 1.00 & 0.44 \\
\hline T3 & 3.84 & 1.41 & 11.75 & 0.70 & 0.86 & 0.40 \\
\hline T4 & 3.53 & 0.76 & 11.00 & 1.75 & 0.44 & 0.31 \\
\hline T5 & 3.56 & 0.77 & 10.00 & 1.50 & 0.50 & 0.23 \\
\hline T6 & 3.60 & 0.79 & 07.15 & 1.10 & 0.57 & 0.26 \\
\hline T7 & 3.52 & 0.65 & 10.50 & 0.72 & 0.32 & 0.15 \\
\hline T8 & 3.50 & 0.72 & 10.00 & 0.79 & 0.38 & 0.19 \\
\hline T9 & 3.42 & 0.66 & 09.50 & 0.90 & 0.27 & 0.11 \\
\hline T10 & 3.44 & 0.63 & 08.75 & 0.33 & 0.25 & 0.10 \\
\hline T11 & 3.30 & 0.61 & 08.20 & 0.43 & 0.23 & 0.09 \\
\hline T12 & 3.28 & 0.58 & 07.70 & 0.55 & 0.23 & 0.07 \\
\hline T13 & 3.21 & 0.48 & 05.50 & 0.22 & 0.19 & 0.06 \\
\hline SE \pm & $\mathbf{0 . 2 1}$ & $\mathbf{0 . 0 7}$ & $\mathbf{0 . 7 1}$ & $\mathbf{0 . 3 5}$ & $\mathbf{0 . 0 4}$ & $\mathbf{0 . 0 1}$ \\
\hline CD at & $\mathbf{0 . 6 2}$ & $\mathbf{0 . 2 2}$ & $\mathbf{2 . 0 9}$ & $\mathbf{1 . 0 5}$ & $\mathbf{0 . 1 4}$ & $\mathbf{0 . 0 3}$ \\
\hline 5 \% & & & & & & \\
\hline
\end{tabular}



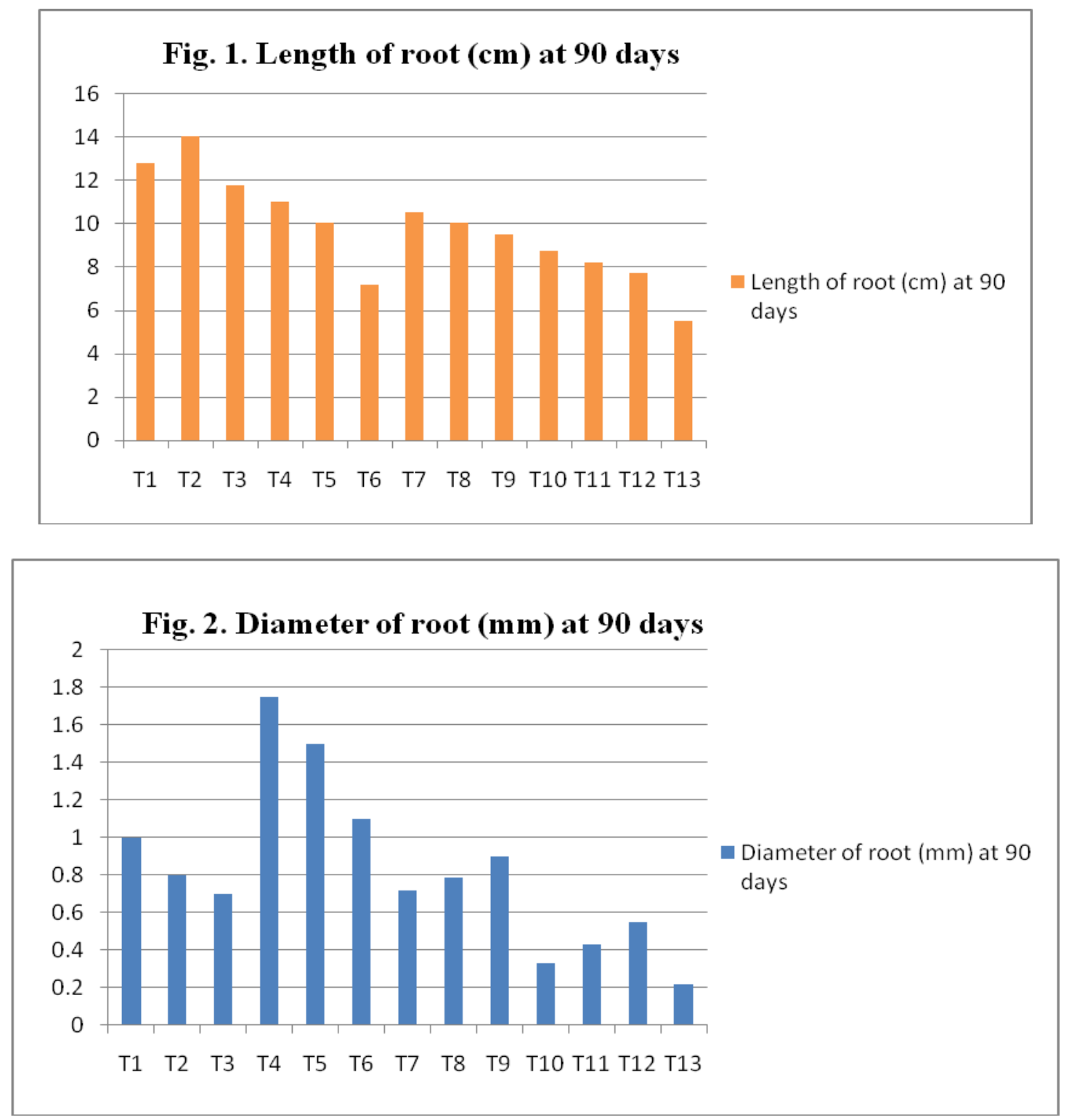

Maximum fresh weight of shoot (3.84 g) at 90 DAP was observed in treatment $\mathrm{T}_{3}$ (IBA 1000 $\mathrm{ppm})$, however it was at par withT $12(3.28 \mathrm{~g})$, $\mathrm{T}_{11}(3.30 \mathrm{~g}), \mathrm{T}_{9}(3.42 \mathrm{~g}), \mathrm{T}_{10}(3.44 \mathrm{~g}), \mathrm{T}_{8}(3.50 \mathrm{~g})$, $\mathrm{T}_{7}(3.52 \mathrm{~g}), \quad \mathrm{T}_{4}(3.53 \mathrm{~g}), \quad \mathrm{T}_{5}(3.56 \mathrm{~g}), \mathrm{T}_{6}(3.60 \mathrm{~g})$, $\mathrm{T}_{1}(3.63 \mathrm{~g})$ and $\mathrm{T}_{2}(3.82 \mathrm{~g})$ and significantly over minimum fresh weight shoot $(3.21 \mathrm{~g})$ control i.e. $\mathrm{T}_{13}$. This might be attributed that auxin increase plasticity of cell wall which in turn increases permeability of cell for moisture and nutrients resulted in enlargement of cell causing more growth of plant parts. Similar results were reported by Thota (2014) in fig and Jana (2015) in Asian pear.
Maximum dry weight of shoot $(1.41 \mathrm{~g})$ at 90 DAP was observed in treatment $\mathrm{T}_{3}$ (IBA 1000 $\mathrm{ppm})$, however it was at par with $\mathrm{T}_{1}(1.27 \mathrm{~g})$ and $\mathrm{T}_{2}(1.35 \mathrm{~g})$, which were significantly superior over rest of the treatments. While, minimum fresh weight $(0.48 \mathrm{~g})$ was observed in treatment control i.e. $\mathrm{T}_{13}$. These results may be attributed to the well-developed root system in such cuttings, which might have tended to promote shoot growth ensuring adequate mobilization of water and nutrients from the soil or substrate to the growing apices. Consequently, there is a faster growth rate of the newly emerged shoots. Similar 
results were reported by Pratima and Rana (2011) in kiwifruit.

The maximum length of root $(14.00 \mathrm{~cm})$ was observed in treatment $\mathrm{T}_{2}$ (IBA $750 \mathrm{ppm}$ ), which were significantly at par with $\mathrm{T}_{1}(12.75$ $\mathrm{cm})$. While, minimum length of root $(5.50 \mathrm{~cm})$ was observed in treatment control i.e. $T_{13}$. Superiority in root length and diameter could be due to higher $\mathrm{C}$ : $\mathrm{N}$ ratio in the tissues of cuttings and greater food reserves in the root. As well as the auxin stimulates the initiation of lateral and adventitious roots because of their effect on cell division.

The results are in agreement with the findings reported by Bemkairema et al., (2012) in passion fruit and Esitken et al., (2003) in wild sour cherry.

Maximum diameter of root $(1.75 \mathrm{~mm})$ was observed in treatment $\mathrm{T}_{4}$ (NAA $500 \mathrm{ppm}$ ), however it was at par with the treatment $\mathrm{T}_{7}$ $(0.72 \mathrm{~mm}), \mathrm{T}_{8}(0.79 \mathrm{~mm}), \mathrm{T}_{2}(0.80 \mathrm{~mm}), \mathrm{T}_{9}$ $(0.90 \mathrm{~mm}), \mathrm{T}_{1}(1.00 \mathrm{~mm}), \mathrm{T}_{6}(1.10 \mathrm{~mm})$ and $\mathrm{T}_{5}(1.50 \mathrm{~mm})$ and significantly superior over rest of the treatments. While, minimum diameter of root $(0.22 \mathrm{~mm})$ was observed in treatment control i.e. $\mathrm{T}_{13}$. This may be due to higher accumulation of photosynthates, metabolites and nutrients. Similar results were reported by Damar et al., (2014) in pomegranate.

Maximum fresh weight of root $(1.00 \mathrm{~g})$ at 90 DAP was observed in treatment $\mathrm{T}_{2}$ (IBA 750 ppm), which was at par with treatment $T_{3}$ and significantly superior over rest of the treatments. While, minimum fresh weight of root $(0.19 \mathrm{~g})$ was observed in treatment control i.e. $\mathrm{T}_{13}$. Maximum fresh weight of root might be due to the fact that in these plants produced longer and more no. of roots. Similar results were reported by Parvez et al., (2007) in peach and Pires et al., (2010) in passion fruit.
Maximum dry weight of root $(0.44 \mathrm{~g})$ at 90 DAP was observed in treatment $\mathrm{T}_{2}$ (IBA 750 ppm), which was significantly superior over rest of the treatments. While, minimum dry weight of root $(0.06 \mathrm{~g})$ was observed in treatment control i.e. $\mathrm{T}_{13}$. The better response in rooting might to be due to the cumulative effect of auxins and the time of propagation in relation to environmental factors. Similar results were reported by Kumar et al., (2008) in passion fruit and Saed (2010) in pomegranate.

\section{References}

Bemkairema, K., Angami, T and Singh, M. S. (2012) Response of different size and growth regulator on cuttings of passion fruit var. Purple (Passiflora edulis var. edulis Sims). The Asian J. of Hort. 7 (2): 515-520.

Campbell, C.W. and R.J. Knight (1983) Passion fruit production, In: Congress Norcofel.8, Spain. Spain Ministerio de Agric. Fisheries and Food.1-8.

Chadha, K. L. (2002) Passion fruit In: Handbook of Horticulture, Directorate of Information and Publications of Agriculture Publishers, Pusa, New Delhi.260-261.

Chand, H. J (1980) Passion fruit In: Tropical and Subtropical Fruits: Composition, properties and uses (Eds. S. Negy and P. E. Shaw), AVI Publishing, Wesport, USA.

Damar, D, A. K. Barholia., R. Lekhi and A. Haldar (2014) Effect of Growth regulators and bio fertilizers on survival of Pomegranate (Punica granatum L.) stem cuttings. Plant Archives Vol.14.No.1, pp.347-350.

Esitken, A., S. Ercisli., I. Sevik and F. Sahin (2003). Effect of Indole -3-Butyric Acid and Different Strains of Agrobacterium rubi on Adventive Root Formation from Softwood and Semi- Hardwood Wild 
Sour Cherry Cuttings. Turk J.Agric.27:37-42.

Jana, B. R., B. Das and S. Kumar (2015) Efficacy of IBA and Determination of Cuttings Size in Pear (Pyrus pyrifolia L.) Int. J. Plant Res. 5 (3):64-67.

Joy, P.P. (2010) Passion fruit: Pineapple Research Station. Vol.1:1-7.

Kumar, S., R. Chithiraichelvan, G. Karunakaran and T. Sakthivel (2008) Studies on propagation of passion fruit cv. Kaveri by cuttings under Coorg conditions. Indian J. Hort. 65(1): 106109.

Panse, V. G and P. V. Sukhatme (1985) Statistical method of Agricultural workers, ICAR Publication, New Delhi.

Parvez, M., M. Zubair., M. Saleem., K. Wali and M. Shah (2007) Effect of Indole Butyric Acid (IBA) and Planting Times On The Growth and Rooting Of Peach Cuttings. Sarhad J. Agric.Vol.23, No.3.

Pires, M. C., J. R. Peixoto and O. K. Yamanishi (2010) Rooting of Passion Fruit Species with Indole-Butyric Acid under Intermittent Misting Condition. ISHS Acta Hort. 894:1 ${ }^{\text {ST }}$ International symposium on Tropical Horticulture.

Pratima, P and V. S. Rana (2011) Effect of pre-conditioning treatments, IBA and collection time on the rooting of Semihardwood cuttings of kiwifruit, Actinidia deliciosa Chev. Int. J. Farm Sci. 1(2):30-36.

Ruggiero, C. and Martins (1987) Implementation of culture and propagation of passion fruit. Legis summa. Pp. 40-57.

Saed, J.Owais (2010) Rooting response of Five Pomegranate Varieties to Indole Butyric Acid Concentration and Cuttings Age. Pak. J. Biol. Sci. 13 (2): 51-58.

Thota, S. K. Madhavi, V. Vani and Sudha (2014) Effect of Type of Cuttings and IBA Concentrations on the Propagation of Fig (Ficus carica) cv. Poona Fig under Open Conditions. Trends In Biosci. 7 (11): 1087-1089.

\section{How to cite this article:}

Parse, R.N., S.B. Mane and Naglot, U.M. 2018. Effect of Different Chemicals on Root Growth Success of Cuttings in Passion Fruit. Int.J.Curr.Microbiol.App.Sci. 7(09): 3139-3144. doi: https://doi.org/10.20546/ijcmas.2018.709.391 